\title{
Firm Age, Size and Profitability Dynamics: A Test of Learning by Doing and Structural Inertia Hypotheses
}

\author{
Ofuan. J. Ilaboya ${ }^{1} \&$ Izien. F. Ohiokha ${ }^{2}$ \\ ${ }^{1}$ Department of Accounting, Faculty of Management Sciences, University of Benin, Benin City Nigeria \\ ${ }^{2}$ Department of Accountancy, Federal Polytechnic, Auchi, Edo state Nigeria \\ Correspondence: Ofuan J Ilaboya, Department of Accounting, Faculty of Management Sciences, University of Benin, \\ Benin City, Edo State, Nigeria
}

Received: February 2, 2016

Accepted: March 8, 2016

Online Published: March 11, 2016

doi:10.5430/bmr.v5n1p29

URL: http://dx.doi.org/10.5430/bmr.v5n1p29

\begin{abstract}
The fundamental objective of this paper is to investigate the relationship between company age, company size and profitability against the background of the learning by doing and structural inertia hypotheses. The study population consists of the universe of companies (202) listed on the Nigerian Stock Exchange Market as at December 2014. A sample of 30 firms was scientifically selected for the study. The analysis was carried out using archival data from 2006 to 2012, comprising of 210 observations. The panel data regression analysis is the technique for data analysis. The choice of the technique is premised on its property of increase data points and control for individual heterogeneity. The usual classical regression assumption tests were effected to ensure the accuracy of the regression model. The study finds a significant positive relationship between firm age, firm size and profitability. The control variable of board size reports a negative and insignificant relationship with profitability. The significant positive relationship between company age and profitability, is a confirmation of the learning by doing hypothesis. However, the positive relationship between size and profitability, negates the hypothesis of structural inertia. Against the backdrop of the research findings, we recommend that the management should strive to increase the scale of operation of businesses and by implication, the size of the business to enhance improved reputation and attractiveness.
\end{abstract}

Keywords: Profitability, Firm age, Firm age, Board size, Structural inertia

\section{Introduction}

The relationship between firm age, firm size and corporate profitability has been a subject of diverse theoretic (learning by doing, liability of obsolescence, senescence and structural inertia theory) and mixed empirical results with some reporting positive relationship (Halil \& Hasan, 2010; Papadogonas, 2007; Akinomi \& Olagunja, 2012; Coad, Segarra and Teruel, 2007; Hui, Radzi, Jenatabadi, Kasim and Radu, 2013 and Balik and Gort, 1993) and others advancing negative relationship (Majumdar, 1997; Dogan, 2013; Hall, 1978; Evans 1957 and Burson 2007).

The learning by doing theory posits that increasing knowledge of effective production techniques will improve the performance of the organisation (Garnsey, 1998). This position is however criticised by the liabilities of senescence internal inefficiency resulting from age (Hannan, 1998) and obsolescence- a mismatch of corporate objectives with the environment of business (Barnet, 1990). The structural inertia theory believes that as organisations grow, it suffers bureaucratic bottlenecks and inflexibility which may metamorphose into the problem of resistance to change - dinosaur dynamics (Hance \& Freeman, 1984).

\subsection{Statement of the Problem}

These internal inconsistencies resulting from different theoretical positions and mixed empirical reactions is an evidence of the inconclusive nature of the relationship between age, size and profitability. The developing economy perspective of the issue has not received its desired attention, hence the paucity of serious empirical consideration even though some attempts have been recorded from the firm size perspective (Babalola, 2013; Akuyomi \& Olagunja, 2012).

The fundamental objective of our contribution is to investigate the relationship between firm age, size and profitability against the backdrop of the inconsistencies above and present a developing country perspective to the 
issue. It appraises the potency of the structural inertia theory and the theory of learning by doing using a dataset from the Nigerian Stock Exchange.

The paper makes a fundamental contribution to knowledge. It has helped to debunk the theory of structural inertia and establish that size confers economics of scale on firms quoted on the Nigerian Stock Exchange. It also confirms the learning by doing theory by showing that firm age has a significant and positive impact on profitability.

The remainder of the paper is organised as follows: following the introduction is section two which focus on the review of the extant literature. Section three addresses the study methodology with emphasis on analytical review and model specification. Section four presents the estimation results and discussion while section five focus on conclusion and suggestion for further research.

\section{State of the Literature}

\subsection{Profitability}

Profitability is the level of profit in relation to the volume of activities of the organisation. Profitability is an index of both performance and efficiency, even though, the level of profitability may not necessarily mean the efficiency of management. Profit and profitability may be used interchangeably. Suffice to say that a difference exists between the two concepts. While profit is an absolute value which describes the difference between revenue and costs, profitability is a relative concept which measures the level of profit in relation to the volume of activities. Profit is synonymous with income, earnings, and margin and returns even though in principle, differences exists among the concepts.

\subsection{Firm Age and Profitability}

Different measures of profitability have been adopted in various researches. In accounting literature, there exist about five (5) variants of profitability index: return on assets, return on capital employed, return on equity, net profit margin and gross profit margin (Ilaboya, 2008). Becker-Blease, Etebari and Bauman (2010) proxy profitability using earnings before interest and tax. According to them, EBIT separates management financing decision from the fundamental earnings power of the company. Most researches have adopted the return on equity and return on asset approach to measuring profitability (Owolabi \& Alu, 2012; Babalola, 2003; Doodann, Tavakoli \& Ivuson, 2005; Oladele \& Olagunju, 2013; Halil \& Jasan, 2012 and Dogan, 2013).

In this contribution, we proxy profitability using the log of profit before interest and tax. The preference for profit before tax is based on the fact that it nulls the effect of the different capital structures and tax rates used by different companies hence allowing for efficient comparison of corporate operations.

Age is the length of time during which a being or thing has existed. We defined firm age as the number of years of incorporation of the company; even though some believe that listing age, should define the age of the company (Shumway, 2001). According to him, listing age is more economical since listing is a defining moment in the company' life. Shumway's argument is debunked from the perspective of the company as a legal personality (Waelchi \& Pdferer. 2011). As a legal person, a company is born through incorporation Gitzmann, 2008; Pickering, 2011). Hence our preference for the year of incorporation as the definition of the age of the company.

The relationship between firm age and profitability is contentious. While some reported the positive and significant relationship between age and profitability (Halil \& Hasan, 2012; Papadogonas, 2007; Akinyomi \& Olagunju, 2012). Others have reported negative relationship (Majumdar, 1997; Dogan, 2013 and Coad, Segarra \& Teruel, 2007). This mixed reaction has made the debate inconclusive.

Majundar (1997) investigated the impact of size and age on firm- level performance of 1020 Indian firms. It was discovered that Indian older firms are more productive but less profitable. In the same vein, Dogan (2013) focused on 200 companies listed on the Istanbul Stock Exchange from 2008 to 2011. The study found a negative relationship between age and profitability. Coad, Segarra and Teruel (2007) using a sample of Spanish firms from 1998 to 2006 found that firm performance improve with the age of the firm and that older firms have a lower level of productivity and profitability.

The negative relationship between firm age and profitability may be ascribed to the Gardner (1965) organismic life cycle analogy that: "like people and plants, organisations have a life cycle...a time of flourishing strength and a gnarled old age when exit becomes almost inevitable". Even though, Penrose (1952) warned against the rigid application of the organismic life cycle analogy since the life cycle of the organisation cannot be predetermined or predicted with reasonable certainty. 
The negative relationship can also be viewed from the perspective of liability of obsolescence in which organizational performance declines with age (Barnet 1990). The decline has been attributed to environmental drift, resulting from rivalry and competition (Utterback \& Abernathy, 1975) and organisational inertia - the syndrome of too big or too old to change. Liabilities of obsolescence arise from growing external mismatch with the environment. In the same vein, the liability of senescence may help to explain the negative relationship between age and profitability. Liability of senescence describes the internal inefficiency arising from organisational aging (Hannan, 1998).

Several other studies have reported a positive relationship between firm age and profitability. Coad, Segarra and Teruel (2007) used a sample of Spanish firms from 1998-2006 and found that performance increases with age. Hui, Ladzi, Jeatabadi, Kasim and Radu (2013) found a positive relationship between age and profitability. The theory of learning by doing, explains the positive relationship, which posits that as the age of the firm increases, there is the likelihood of improvement in their productive efficiency over time by learning from their experience (Balik \& Gort, 1993). According to Garnsey (1998:54):

"New firms are hampered by their need to make search processes in the prelude to every new problem they counter. As learning occurs, benefits can be obtained from the introduction of a repertoire of problem-solving procedures...eliminating open search from the problem-solving response greatly reduces the labour and time required to address recruitment problem".

The result is consistent with the findings of Coad et al (2007); Hui et al (2013); and conforms to the Garnsy (1998) and Balk and Gort (1993) positions on learning by doing hypothesis. The result is at variance with the findings of (Majumdar, 1997; Dogan, 2003) who found a negative relationship between firm age and profitability. The internal inconsistency of the different positions advance on the relationship between age and profitability brings to the fore a research question for further study:

RQ1 What is the relationship between firm age and profitability in Nigerian listed companies? We hypothesized in a null form, a non-significant relationship between firm age and profitability (RH1).

\subsection{Firm Size and Profitability}

The firm size and profitability dynamics have enjoyed robust theoretic and empirical position starting from the foremost Gibrat (1931) hypothesis which holds that the growth rate of a firm is not a function of its size. About 50 decades after the Gibrat hypothesis, studies have shown that the relationship between firm size and growth is a decreasing one (Hall, 1987 and Evans 1987). However in more recent studies, a positive relationship has been established between the size of the firm and growth (Duncan \& Hughes, 1994). The availability of more accurate and complete data set has been adduced as the reason for the conflict (Cabral \& Mata, 2003).

In line with the Gibrat (1931) proportionate growth hypothesis, Bharni (2007) investigated the relationship between size and profitability of 250 Icelandic firms from five years and found a weak and insignificant relationship between size and profitability. In the same vein, Molyneux and Wilson (2004) studied European banks and found a weak evidence of consistent size and profitability relationship.

In addition, to the Hall (1987) and Evans (1987), decreasing relation between growth and size, Goddard, Tavakoli and Wilson (2005) studied 4 European countries from 1993-2004 and found a negative relationship between size and profitability. In the same vein, Ammar (2003) found a negative relationship between size and profitability for firms with a turnover of 50million dollars. Burson (2007) in a linear specification of the size - profit relationship, reported a negative influence of firm size on profitability.

The weak and negative relationship has been explained by the structural inertia theory (Hannan \& Freeman, 1984) which states that as the organisation becomes larger, the volume of bureaucracy increases and this may cause stiff resistance to change which will ultimately decrease the level of profit. Even though this position contradicts the liability of smallness theory which says that expectations of success are brighter for large organisations and that on the average, small firms have a higher likelihood of failure as result of limited access to capital, problem is attracting and retaining skilled workers and higher administrative costs (Aldrich \& Anster, 1986).

A positive relationship has also been established between firm size and profitability. Halil and Hasan (2012) focused on 143 companies listed on the Istanbul Stock Exchange from 2005-2011 and found a positive relationship between firm size and profitability. Papadogonas (2007) investigated 3,035 Greece manufacturing companies and also found a positive relationship between size and profitability. In the same vein, Akinyomi and Olagunju (2012) investigated the effect of size on profitability using companies listed on the Nigerian Stock Exchange market from 2005-2012 and found a positive relationship. Velnampy and Nimalathasum (2010) also found a positive and significant relationship. 
The positive impact of size on profitability may be viewed from the economics of scale perspective. Economics of scale is the cost advantage that enterprise obtain due to size. As output increases, the average unit cost decreases.

The result corroborates the findings of Halil and Hasan (2012); Papadogonas (2007); Akinyomi and Oladguju (2012) and Velnampy and Nimalathasan (2010) but deviates from those of Hall (1987); Evans (1987); Goddard, Tavakoli and Wilson (2005); Ammar (2005) and Burson (2007) who found negative relationship between firm size and profitability.

The above review of the literature has shown that a concerted effort has been made in addressing firm size and profitability. However, the mixed reports mean opportunities still exist to improve our understanding of the concept. From these possibilities evolved a research question for further study:

RQ2 what is the relationship between firm size and profitability? We hypothesized in null form a non-significant relationship between firm size and profitability (RH2)

\subsection{Board Size and Profitability}

The board size variable is a control variable introduced into the explanatory variable of age and firm size. There are two strands of literature on the board size - corporate profitability nexus. While the first, addresses a positive relationship between board size and corporate profitability (Mak \& Li, 2001; Adams \& Mehran, 2005; Dalton \& Dalton, 2005) others found a negative relationship between board size and profitability (Guest, 2009; Jensen, 1993; Lipton \& Lorsch, 1992).

The opponents of board size argued for small size of the board and stressed that larger boards are likely to function properly. Jensen (1993) recommended board size of seven or eight. The proponents of board size and corporate profitability believed that larger boards have collective information on the factors that help increase firm value. The diverse professional advantage of a large board can also bring into bear the verse experience of the board members hence helping to increase the profitability of the firm. These inconsistencies necessitate our third research question:

RQ3: What is the relationship between board size and profitability? We hypothesised in the null form, a non-significant relationship between board size and profitability. (RH3)

\section{Methods}

\subsection{Analytical Framework and Model Specification}

The framework for the analysis of the relationship between firm age, firm size and corporate profitability is bi-dimensional, combining the theory of learning by doing and the theory of structural inertia.

From the perspective of Hannan and Freeman (1984) theory of structural inertia, it is believed that as the organisation grow larger, bureaucracy increases, inflexibility sets in which may cause resistance to change and ultimately decrease the level of profitability, therefore,

$$
d \Pi_{1}<0
$$

This means a functional relationship exist between company size and profitability. This association may be expressed as Profitability $=f($ FSIZE $)$

From the perspective of the theory of learning by doing, increased knowledge of productive production techniques are expected to enhance the productivity of the firm (Garnsey, 1998). Older firms benefit from inter-corporate relationships, industrial experience of management and accumulated resources. Therefore,

$$
d \Pi_{1}>0
$$

Against the backdrop of the above, it is expected that a functional relationship exists between company age and profitability of the form: Profitability $=f(F A G E)$

Combining equations (2) and (4) we have: Profitability $=f($ FSIZE, FAGE)

Introducing the control variable of Board Size, equation (5) is transformed as:

$$
\text { Profitability }=f(F S I Z E, F A G E, \text { BSIZE) }
$$




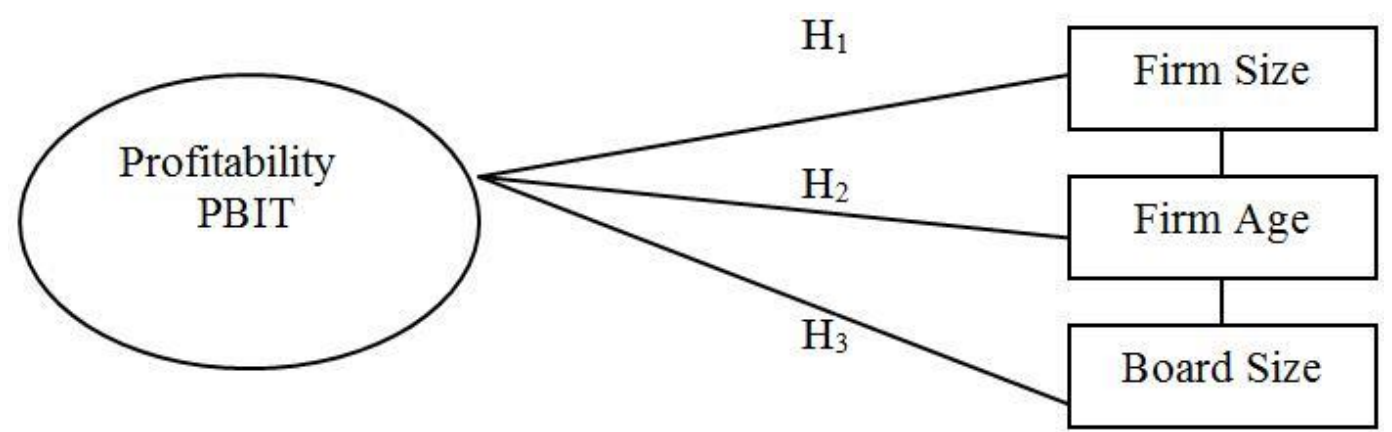

Figure 1. Schematic representation of the research model

Equation (6) is expressed in econometric form as:

$$
\begin{aligned}
& L P B I T=\beta_{0}+\beta_{1} F S I Z E+\beta_{2} F A G E+\beta_{3} B S I Z E+\varepsilon \\
& \operatorname{PBIT}_{i t}=\beta_{0}+\beta_{1} F S I Z E_{i t}+\beta_{2} F A G E_{i t}+\beta_{3} B S I Z E_{i t}+\varepsilon_{i t}
\end{aligned}
$$

Where: $L P B I T=L o g$ of profit before interest and tax; LFSIZE = Log of total assets which measure FSIZE; FAGE = Firm age of incorporation; BSIZE = Board size; $\mathcal{E}=$ error term; $i=$ company; $t=$ time covered .

Aproiri expectations: A negative coefficient is expected, between firm size and profitability i.e. $\beta_{1}<0$ and a positive relationship is expected between firm age and board size and profitability of the form: $\beta_{2}, \beta_{3}>0$.

\begin{tabular}{|c|c|c|c|c|}
\hline Variable & Code & Operational Definition & Source & Apriori \\
\hline Profitability & PBIT & $\begin{array}{l}\text { Log of profit before interest } \\
\text { and tax }\end{array}$ & Becker-Blease et al (2010) & \\
\hline Firm Size & FSIZE & Log of total assets & $\begin{array}{l}\text { Bjarni, 2007; Akinyomi \& Olagunju, } \\
2012\end{array}$ & -ve \\
\hline Firm Age & FAGE & $\begin{array}{l}\text { Age of the company since } \\
\text { incorporation }\end{array}$ & $\begin{array}{l}\text { Majumdar, 1997; Dogan, 2013; Halil } \\
\text { \& Hasan, 2012. }\end{array}$ & $+\mathrm{ve}$ \\
\hline Board Size & BSIZE & Total number of board & $\begin{array}{l}\text { Lipton \& Lorsch, 1997; Ilaboya \& } \\
\text { Obaretin, } 2015\end{array}$ & $+\mathrm{ve}$ \\
\hline
\end{tabular}

\subsection{Operationalisation of Variables}

Source: Researchers' Compilation 2015

\subsection{Data and Source}

Our sample of 30 firms conforms to balanced panel data format. We used firm-level data sourced from the Nigerian Stock Exchange Market for thirty companies from 2006-2012. The variables were derived from content analysis of the annual financial statements for the relevant years. The sample of 30 firms was scientifically determined using the Yamane (1967) approach. The choice of panel data approach is premised on the fact that it provides larger data points, increase the degree of freedom and reduces the problem of collinearity of the explanatory variables. 


\section{Results and Discussion}

\subsection{Descriptive Statistics}

Table 1. Results of the Descriptive Statistics

\begin{tabular}{lcccc}
\hline & BSIZE & FAGE & LFSIZE & LPBT \\
\hline Mean & 8.923810 & 37.20476 & 4.303857 & 3.899381 \\
Median & 9.000000 & 36.00000 & 4.320000 & 4.080000 \\
Maximum & 15.00000 & 86.00000 & 5.840000 & 4.940000 \\
Minimum & 3.000000 & 7.000000 & 3.070000 & 2.370000 \\
Std. Dev. & 2.321917 & 16.28311 & 0.515648 & 0.618834 \\
Skewness & 0.058099 & 0.586849 & -0.333430 & -0.563845 \\
Kurtosis & 2.543708 & 3.140089 & 2.548026 & 2.501849 \\
& & & & \\
Jarque-Bera & 1.939912 & 12.22545 & 5.678592 & 13.29859 \\
Probability & 0.379100 & 0.002215 & 0.058467 & 0.001295 \\
Sum & & & & \\
Sum Sq. Dev. & 1874.000 & 7813.000 & 903.8100 & 818.8700 \\
Observations & 1126.781 & 55414.20 & 55.57158 & 80.03782 \\
\hline
\end{tabular}

Source: Researcher's computation, 2015

The variable of board size shows a maximum board of 15 members and a minimum of 3 with an average board size of about 9 members meaning that on the average, the board size of the selected companies is 9 members.

The maximum age of the selected companies is 86, with a minimum age of 7 and a mean or average age of 37.20476. The log of firm size has a maximum of 4.94, a minimum of 2.37 and average size of 4.303857 which translates into \#20 130.613 01. The maximum profit before tax of the selected companies is 4.94 (\#87 096B), with a minimum profit of 2.37 (\#234 $422851 \mathrm{M}$ ) and a mean or average value of 3.899351 (\#3 931.968 853).

The standard deviation of the variables show the relatively low level of variability, except FAGE with standard deviation statistic of 16.28311 which signifies higher level of variability or dispersion. BSIZE reported standard deviation of 2.321917; FSIZE is 0.515648 and LPBT is 2.370000 respectively. The relatively low level of dispersion as presented in the standard deviation values is an indication of the quality of the regression data.

The Jarque-Bera statistics reported relatively large value except BSIZE with a JB statistics of 1.939912. The large values of JB statistics show that the variables are normally distributed.

The skewness statistics shows that FAGE is positively skewed, meaning their average value is greater than the median value (i.e. $37.20476>36.00000$ ). This means the data will peak at a smaller value than 37.20476. The skewness value of BSIZE is relatively close to zero (0.06) which means the mean value of 8.923810 is almost equal to 9.0000 which mean perfectly symmetric data. The variables of FSIZE and PBT are negatively skewed indicating the average values (4.306857 and 3.89938) are less than the median values of (4.320000 and 4.08000). The Kurtosis statistics are all positive which signifies they all exhibit high top peak near the mean of the data. 


\subsection{Correlation Analysis}

Table 2. Results of the Spearman-Rank-Order Correlation Test

\begin{tabular}{l|llll}
\hline $\begin{array}{l}\text { Correlation } \\
\text { t-Statistic } \\
\text { Probability }\end{array}$ & BSIZE & FAGE & LFSIZE & LPBT \\
\hline BSIZE & 1.000000 & & & \\
& - & & & \\
FAGE & ---- & & & \\
& 0.320757 & 1.000000 & & \\
& 4.884090 & ---- & & \\
LFSIZE & 0.0000 & ---- & & \\
& 0.234439 & 0.216937 & 1.000000 & \\
& 3.478062 & 3.205041 & ----- & \\
LPBT & 0.0006 & 0.0016 & ---- & \\
& 0.026263 & 0.057191 & 0.524393 & 1.000000 \\
& 0.378904 & 0.826167 & 8.882113 & ---- \\
\hline
\end{tabular}

Source: Researcher's Computation, 2015

The Spearman-rank-order correlation approach was adopted. The result of the test shows that the variables within themselves exhibit perfect correlation of 1.00 which is however expected. The correlation coefficients did not signify any problem of multicollinearity. The highest correlation coefficient is 0.524393 between the explanatory variable of FSIZE and PBT. This is however not a cause for concern. The variables all show a positive correlation.

To further strengthen the result of the correlation coefficient, we carried out a variance inflation test.

Table 3. Results of the Variance Inflation Factor Test

\begin{tabular}{llll}
\hline Variable & $\begin{array}{l}\text { Coefficient } \\
\text { Variance }\end{array}$ & $\begin{array}{l}\text { Uncentered } \\
\text { VIF }\end{array}$ & $\begin{array}{l}\text { Centered } \\
\text { VIF }\end{array}$ \\
\hline C & 0.055893 & 69.75587 & NA \\
BSIZE & 0.000252 & 24.51510 & 1.229953 \\
FAGE & $8.08 \mathrm{E}-06$ & 12.97329 & 1.013225 \\
LFSIZE & 0.003541 & 76.24012 & 1.243713
\end{tabular}

Source: Researcher's Computation, 2015

The centered VIF of all the variables reported very small values. None of the variables had a value up to the benchmark of 10.00. BSIZE reported a centered VIF of 1.29953. FAGE 1.013225 and FSIZE 1.243713. This means there is no problem of multicollinearity in the regression variables.

\subsection{Diagnostic Tests}

To ensure the adequacy of our regression model, we carried out the usual regression assumption tests as: 


\subsection{Serial Correlation Test}

Table 4. Results of the Breusch-Godfrey LM Test

\begin{tabular}{llll}
\hline Breusch-Godfrey Serial Correlation LM Test: & \\
\hline F-statistic & 7.465104 & Prob. F(2,24) & 0.3225 \\
Obs*R-squared & 9.135577 & Prob. Chi-Square(2) & 0.2171
\end{tabular}

\section{Source: Researcher's Computation, 2015}

The test of serial correlation of the variables was carried out using the Breusch-Godfrey approach. The results of the analysis reported probability values of $\mathrm{p}=0.3225,0.2771>\mathrm{p}=0.05$ hence the null hypothesis of a serial correlation between the regression variables was rejected for the alternate hypothesis of no serial correlation.

\subsection{Heteroskedasticity}

Table 5. Results of the Heteroskedasticity Test

\begin{tabular}{llll}
\hline Heteroskedasticity Test: & Breusch-Pagan-Godfrey & \\
\hline F-statistic & 1.862072 & Prob. F(3,26) & 0.1608 \\
Obs*R-squared & 5.305684 & Prob. Chi-Square(3) & 0.1507 \\
Scaled explained SS & 11.96193 & Prob. Chi-Square(3) & 0.0075 \\
\hline
\end{tabular}

\section{Source: Researcher's Computation, 2015}

The heteroskedasticity test revealed the presence of homoskedastic residuals since the probability values of $\mathrm{p}=$ 0.1608 and $0.1507>\mathrm{p}=0.05$. Hence, the null hypothesis of heteroskedastic residuals was rejected.

\subsection{Results of the Regression Analysis}

Table 6. Result of the Panel Least Square Regression

\begin{tabular}{lclcl}
\hline Variable & Coefficient & Std. Error & t-Statistic & Prob. \\
\hline C & 0.612630 & 0.279123 & 2.194838 & 0.0293 \\
BSIZE & -0.037320 & 0.014997 & -2.488393 & 0.0136 \\
FAGE & 0.004023 & 0.002082 & 1.932235 & 0.0547 \\
LFSIZE & 0.806275 & 0.064575 & 12.48593 & 0.0000 \\
\hline R-squared & 0.440664 & Mean dependent var & 3.899381 \\
Adjusted R-squared & 0.432519 & S.D. dependent var & 0.618834 \\
S.E. of regression & 0.466176 & Akaike info criterion & 1.330359 \\
Sum squared resid & 44.76801 & Schwarz criterion & 1.394113 \\
Log likelihood & -135.6877 & Hannan-Quinn criter. & 1.356132 \\
F-statistic & 54.09800 & Durbin-Watson stat & 1.879685 \\
Prob(F-statistic) & 0.000000 & & \\
\hline
\end{tabular}

\section{Source: Researcher's Computation, 2015}

The Panel Least Square Regression revealed a DW statistics of (1.879685), which is substantially close to 2.00 benchmarks and signifies the absence of serial correlation. This result further strengthened the Breusch-Godfrey serial correlation test in Table 4.The adjusted R-squared value of 0.432519 means the explanatory variables of FSIZE; BSIZE and FAGE explain about $43 \%$ of the systematic variation in the level of profit of the selected organizations. The f-statistics of 54.09800 and the associated probability of 0.0000 shows that a significant linear relationship exists between profitability and the independent variables of firm size, board size and firm age. A close 
examination of the coefficient of the explanatory variables show that the coefficient of BSIZE is different from our apriori expectation of positive relationship. All the variables were significant.

\subsection{Hausman Test}

Table 7. Result of the Hausman Fixed/Random Effect

\begin{tabular}{llll}
\hline $\begin{array}{l}\text { Correlated Random Effects - Hausman Test } \\
\text { Equation: Untitled }\end{array}$ & & & \\
Test cross-section random effects & & & \\
\hline Test Summary & $\begin{array}{l}\text { Chi-Sq. } \\
\text { Statistic }\end{array}$ & Chi-Sq. d.f. & Prob. \\
\hline Cross-section random & 31.520150 & 3 & 0.0000 \\
\hline
\end{tabular}

Cross-section random effects test comparisons:

\begin{tabular}{lllll} 
Variable & Fixed & Random & Var(Diff.) & Prob. \\
\hline BSIZE & 0.002233 & -0.000799 & 0.000007 & 0.2576 \\
FAGE & 0.033167 & 0.019802 & 0.000009 & 0.0000 \\
LFSIZE & 0.127587 & 0.234164 & 0.000377 & 0.0000
\end{tabular}

Source: Researcher's Computation, 2015

The choice of the random and fixed effect model is hinged on the probability value of the Hausman test. From the result, the test summary reported a probability value of $\mathrm{p}=0.0000<\mathrm{p}=0.05$ which signifies a preference for the fixed effect model.

4.8 Fixed Effect Model (FEM)

Table 8. Results of the Fixed Effect Model

\begin{tabular}{lllll}
\hline Variable & Coefficient & Std. Error & t-Statistic & Prob. \\
\hline C & 2.096374 & 0.237479 & 8.827619 & 0.0000 \\
BSIZE & 0.002233 & 0.010755 & 0.207662 & 0.8357 \\
FAGE & 0.033167 & 0.004532 & 7.319054 & 0.0000 \\
LFSIZE & 0.127587 & 0.054083 & 2.359108 & 0.0194 \\
\hline
\end{tabular}

Effects Specification

\begin{tabular}{llll}
\hline Cross-section fixed (dummy variables) & & \\
\hline R-squared & 0.967233 & Mean dependent var & 3.899381 \\
Adjusted R-squared & 0.961309 & S.D. dependent var & 0.618834 \\
S.E. of regression & 0.121724 & Akaike info criterion & -1.230788 \\
Sum squared resid & 2.622575 & Schwarz criterion & -0.704814 \\
Log likelihood & 162.2328 & Hannan-Quinn criter. & -1.018156 \\
F-statistic & 163.2758 & Durbin-Watson stat & 1.767382 \\
Prob(F-statistic) & 0.000000 & & \\
\hline
\end{tabular}

Source: Researcher's Computation, 2015

The results of the fixed effect model reported R-squared and adjusted R-squared values of 0.967233 and 0.961309 respectively. This means $96 \%$ of the cross-sectional variability in profitability is accounted for by the explanatory 
variables of firm size, firm age and board size. The f-statistic of 163.2758 and the associated probability value of 0.0000 is robust and suggests a significant linear relationship between profitability and the explanatory variables. The DW statistic of 1.767382 is substantially close to 2.00 and signifies the absence of serial correlation. The above measures of the statistical fitness of the regression estimate (the coefficient of determination and the f-statistics) are significant at the $5 \%$ level.

The statistical significance of FAGE is beyond the likelihood of chance. The variable of firm age sustained significance with a robust t-value of 7.319054 and an associated probability value of 0.0000 . The positive coefficient of 0.033167 signifies that a $10 \%$ increase in the age of the firm will increase profitability by $3.3167 \%$. The result validates our alternate hypothesis of a significant relationship between age of the firm and profitability. The result is consistent with the findings of Coad et al (2007); Hui et al (2013), and conforms to the Garnsy (1998) and Bahk and Gort (1993) positions on the learning by doing hypothesis. The result is however at variance with the findings of Majumdar (1997); Dogan (2003), who found a negative relationship between firm age and profitability.

Firm size was found to have a significant positive relationship with profitability. The variable reported a t-value of 2.35910 , a probability value of 0.0194 and a positive coefficient of 0.127587 at the $5 \%$ level of significance. The implication of this is that as the size of firm increases, profitability is likely to move upward by about $13 \%$. Hence, the null hypothesis of no significant relationship between firm size and profitability was rejected. The result is at variance with our apriori expectation of negative coefficient. It, however, corroborates the findings of Halil and Hasan (2012); Papadogonas (2007); Akinyomi and Olagunju (2012) and Velnampy andNimalathasan (2010). The result is inconsistent with the reports of Hall (1987); Evans (1987); Goddard, Tavakoli and Wilson (2005); Ammar (2003) and Burson (2007) who found a negative relationship between firm size and profitability.

Board size was found to have a positive but insignificant relationship with profitability. The variable reported a coefficient of 0.002233 , insignificant $t$-value of 0.207662 and a probability value of 0.8357 hence we could not reject the null hypothesis of an insignificant relationship between board size and profitability.

\section{Conclusion}

The study investigates the link between firm age, firm size and corporate profitability in a sample of 30 firms quoted on the Nigerian Stock Exchange market. We found a significant positive relationship between firm age and profitability. The result is robust and consistent with the learning by doing hypothesis which states that increase knowledge of effective production techniques increases the company's productivity. Our findings indicate that increase firm size results in higher level of profitability. The finding debunks the theory of structural inertia in Nigeria companies and affirms the economics of scale hypothesis. The control variable of board size is negatively related to profitability which is however at variance with our apriori expectation of positive coefficient. The relationship is however statistically insignificant.

The study is limited by the fact that it could not establish the behaviour of profit beyond the mean age of 37 years and mean company size of \#20.131Billion. Further research using values beyond the mean age and company size could offer evidence useful to establish the maximum age and size that will cause the level of profitability to decline.

\section{References}

Babaola, Y. A. (2013). The effect of firm size on firms profitability in Nigeria. Journal of Economics and Sustainable Development, 4(5), 90-94.

Balk, B. H. \& Gort, M (1993). Decomposing learning by doing in new plants. Journal of Political Economy, 101(4), 561-583. http://dx.doi.org/10.1086/261888

Barron, D. N. West, E. \& Hannah, M. T. (1994). A time to growth and a time to die. Growth and mortality of credit unions in New York 1910-1990. American Journal of Sociology, 100(2), 381-421. http://dx.doi.org/10.1086/230541

Baumol, W. J. (1959). Business Behaviour, Value and Growth. New York MacMillan.

Becker-Blease, J. R., Kaen, T. K, Eteban, A. \& Bauman, H. (2010). Employees, firm size an profitability in U.S manufacturing industries. Investment Management and Finance Innovation, 7(2), 7-23.

Bohuzi, G. \& Secchi, A. (2006). Explaining the distribution of firms growth rates. Rand Journal of Economics, 37, 234-263.

Coad, A. I. Segarra, A. \& Teruel, M. (2007). Like milk or wine does performance improve with age? The Papers on Economic and Evolution Working Paper, 1006. 
Dogan, M. (2013). Does firm size affect the firm profitability: Evidence from Turkey data of 200 companies active in the Instanbul Stock Exchange between 2008-2011. Research Journal of Finance and Accounting, 4(4), 53-59.

Garnsey, E. (1998). A theory of the early growth of the firm. Industrial and Corporate Change, 7(3), 523-556. http://dx.doi.org/10.1093/icc/7.3.523

Gitzmann, N. (2008). Legal personality of the corporate and international criminal law: Gobalisation, corporate human rights abuses and the Rorne statue. Queensland Law Student Review, 1(1), 36-54.

Goddard, J., Tavakoli, M. \& Wilson, J. (2005). Determinants of profitability in European Manufacturing and Service. Evidence from dynamic panel model. Applied Financial Economics, 15, 1209-1282. http://dx.doi.org/10.1080/09603100500387139

Guest, P. M. (2009). The impact of board size on firm performance: Evidence from the UK. The European Journal of Finance, 15(4), 1385-1404. http://dx.doi.org/10.1080/13518470802466121

Guiso, L. \& Rustichini, A. (2010). Understanding the size and profitability of firms: The role of biological factor. Presented in Conference on New Directions in Applied Microeconomic Nyu-Villa la Pietra.

Halil, E. A. \& Hassan, A. (2012). The effect of firm size on profitability: An empirical Icelandic funds Bitrost. Journal of Social Sciences, 1, 33-42.

Hayne, W. R. (2011). The learning-by-doing principle. Behavioural Development Bulletin, 11, 1-19.

Ilaboya, O. J. (2008). Advanced Financial Accounting. Benin City: Midex Publishing.

Ilaboya, O.J. \& Obaretin, O. (2015). Board characteristics and firm performance: Evidence from Nigerian quoted companies. Academic Journal of Interdisciplinary Studies, 4(1), 283-290. http://dx.doi.org/10.5901/mjss.2015.v4n1p283

Lee, J. (2009). Does size matter in firm performance? Evidence from U.S public firms. International Journal of Economics and Business, 16(2), 189-203. http://dx.doi.org/10.1080/13571510902917400

Loderer, C. \& Waelchi, (2001). Firm age and governance fronties in finance conference in Bank Canada 2011.

Majumdar, S. K. (1997). Impact of size and age on firm-level performance: Some evidence from India. Review of Industrial Organisation, 12, 231-241. http://dx.doi.org/10.1023/A:1007766324749

Molyneux, P. \& Wilson, J. (2004). The profitability of European banks: Cross sectional and dynamic panel analysis. The Manchester School, 72, 363-383. http://dx.doi.org/10.1111/j.1467-9957.2004.00397.x

Papatogonas, E. M. (2007). Financial performance of large and small firms: Evidence from Greece. International Journal of Financial Service Management, 2(1/2), 14-20. http://dx.doi.org/10.1504/IJFSM.2007.011668

Pickering, M. A. (2011). The company as a separate legal entity. The Modern Law Review, 31(5), 481-554. http://dx.doi.org/10.1111/j.1468-2230.1968.tb01206.x

Shumway, T. (2001). Forecasting bankruptcy more accurately: A simple hazard model. Journal of Business, 74, 101-124. http://dx.doi.org/10.1086/209665 